\title{
Pollen Germination in vitro
}

\author{
Jayaprakash $\mathrm{P}$
}

Additional information is available at the end of the chapter

http://dx.doi.org/10.5772/intechopen.75360

\begin{abstract}
Pollen germination in vitro is a reliable method to test the pollen viability. It also addresses many basic questions in sexual reproduction and particularly useful in wide hybridization. Many pollen germination medium ranging from simple sugars to complex one having vitamins, growth regulators, etc. in addition to various minerals have been standardized to germinate pollen artificially. The different media, successful pollen germination methods, procedures from pollen germination studies with wheat, rye, brinjal, pigeonpea and its wild relatives are discussed.
\end{abstract}

Keywords: in vitro pollen germination, grasses, PGM, pollen germination method

\section{Introduction}

Pollen germination in the stigmatic tissue of Portulaca was first observed as early as 1824 by Amici and later he observed the germinating pollen tube entering ovule. Pollen acts as a vehicle for the transfer of male gametes to embryo of female plant. Pollen viability is an important factor in successful hybridization which may last from few minutes mostly in selfpollinated crops to many hours or days in cross pollinated crops. Assessing pollen viability is very crucial in artificial pollination especially involving different species or genera. Among diverse techniques used to assess pollen viability, in vitro pollen germination is the most reliable method. Pollen has been germinated in variety of media which differs from species to species and even for different varieties of a crop [1,2]. Linskens [3] used simple sucrose/boric acid media and later many complex medium have been reported with addition of polyethylene glycol, various amino acids, etc. [4-6]. Among the many PGMs the one developed by Brewbaker and Kwack [7] has been widely used with some alterations. 
A brief discussion was made in this chapter to develop a pollen germination protocol for a crop/species.

\section{Different pollen germination media and methods}

\subsection{Pollen germination medium}

The composition of some of the successful media used pollen germination are given below Brewbaker and Kwack medium [7]

- $10 \%$ sucrose

- $100 \mathrm{mg} \mathrm{l}^{-1}$ boric acid

- $300 \mathrm{mg} \mathrm{l}^{-1}$ calcium nitrate

- $200 \mathrm{mg} \mathrm{l}^{-1}$ magnesium sulfate

- $100 \mathrm{mg} \mathrm{l}^{-1}$ potassium nitrate

Roberts medium [8]

- $20 \%$ sucrose

- $10 \mathrm{mg} \mathrm{l}^{-1}$ boric acid

- $362 \mathrm{mg} \mathrm{l}^{-1}$ calcium chloride

- $100 \mathrm{mg} \mathrm{l}^{-1}$ potassium nitrate

- Tris 60-130 $\mathrm{mg} \mathrm{l}^{-1}$

PEG medium [4]

- 0.1 to 1.1 M PEG 400,

- $100 \mathrm{mg} \mathrm{l}^{-1}$ Boric acid

EACA medium [1]

- $37.5 \%$ sucrose

- $100 \mathrm{mg} \mathrm{l}^{-1}$ potassium nitrate

- $15 \%$ PEG 4000

- $200 \mathrm{mg} \mathrm{l}^{-1}$ magnesium sulfate

- $250 \mathrm{mg} \mathrm{l}^{-1}$ boric acid

- E amino caproic acid (EACA)-0, 100, 250, 500, 750 or

- $300 \mathrm{mg} \mathrm{l}^{-1}$ calcium $1000 \mathrm{mg} \mathrm{l}^{-1}$ nitrate

- $1 \%$ agar

Raffinose medium [9].

- $0.75 \mathrm{M}$ raffinose, 
- $100 \mathrm{mg} \mathrm{l}^{-1}$ boric acid,

- $300 \mathrm{mg} \mathrm{l}^{-1}$ calcium chloride

Peptone PGM of Wheat [2] (Figure 1)

- $19 \%$ Maltose

- $13 \%$ PEG 6000

- $50 \mathrm{mg} \mathrm{l}^{-1}$ boric acid

- $30 \mathrm{mg} \mathrm{l}^{-1}$ calcium nitrate

Tryptone PGM of rye [10]

- $19 \%$ Maltose

- $13 \%$ PEG 6000

- $50 \mathrm{mg} \mathrm{l}^{-1}$ boric acid

Agarose medium [11]:

- $0.5 \%$ agarose

- $18 \%$ sucrose

- $0.01 \%$ boric acid

- $1 \mathrm{mM} \mathrm{CaCl}_{2}$

- $1 \mathrm{mM} \mathrm{Ca}\left(\mathrm{NO}_{3}\right)_{2}$
- 80-100 $\mathrm{mg} \mathrm{l}^{-1}$ peptone

- BK salts

- $1 \%$ agar
- $30 \mathrm{mg} \mathrm{l}^{-1}$ calcium nitrate

- BK salts

- $1 \%$ agar

A basic medium contains a sugar, calcium nitrate and boric acid to which poly ethylene glycol, vitamins, amino acids, growth regulators etc. are added to make a complete pollen germination medium. The $\mathrm{pH}$ and temperatures are also important factors.

\subsection{Pollen germination methods}

Pollen is collected from freshly opened flowers and enough pollen is dusted over medium and culture by any one of the following methods:

- Cavity slide technique (Rangaswamy and Shivanna $[12,13]$ ) : It is used for liquid pollen germination medium(PGM). A drop of medium is placed in the cavity, pollen is dusted over and it is covered with a dust free cover slip with its periphery sealed with Vaseline. It creates a required relative humidity inside. The slide is placed inversely over a pair of glass 
rods in a humid chamber. A Petri dish is used as humid chamber where a moist filter paper is placed inside the lid.

- Agarified medium in Petri dishes [14]: Pollen was extracted from fresh buds (with bud break) and was spread evenly on a drop of medium in a Petri dish and covered with Petri plate lined with moist filter paper. The plats were incubated in a BOD incubator with a temperature of $18^{\circ} \mathrm{C} / 20.5^{\circ} \mathrm{C}$ depending on the pollen sample

- PGM droplet technique [15]: In a Petri dish a droplet of pollen germination medium was placed using a glass rod. Thus drops of different media could be placed within few centimeter distance between them For example nine media can be placed in $3 \times 3$ fashion (Figure 2).

$\begin{array}{lll}\text { 1-Medium A } & \text { 2-Medium B } & \text { 3-Medium C } \\ \text { 4-Medium D } & \text { 5-Medium E } & \text { 6-Medium F } \\ \text { 7-Medium G } & \text { 8-Medium H } & \text { 9-Medium I }\end{array}$

Further in order to have a better visualization, a drop of stain was placed carefully over the medium droplet before observation. The extra stain was removed with a piece of dried filter paper. (Acetocarmine, and components of Alexander stain viz., Malachite green, Orange G, Aniline Blue and acid fuchsine may be used).

- The cellulose membrane/agarose culture apparatus [11]: Rectangular agarose pad was prepared over a microscopic slide with PGM containing $0.5 \%$ agarose. Appropriate size of cellulose membrane was cut and layered over agarose pad. The pollen is placed over the membrane and cultured in a moist chamber.
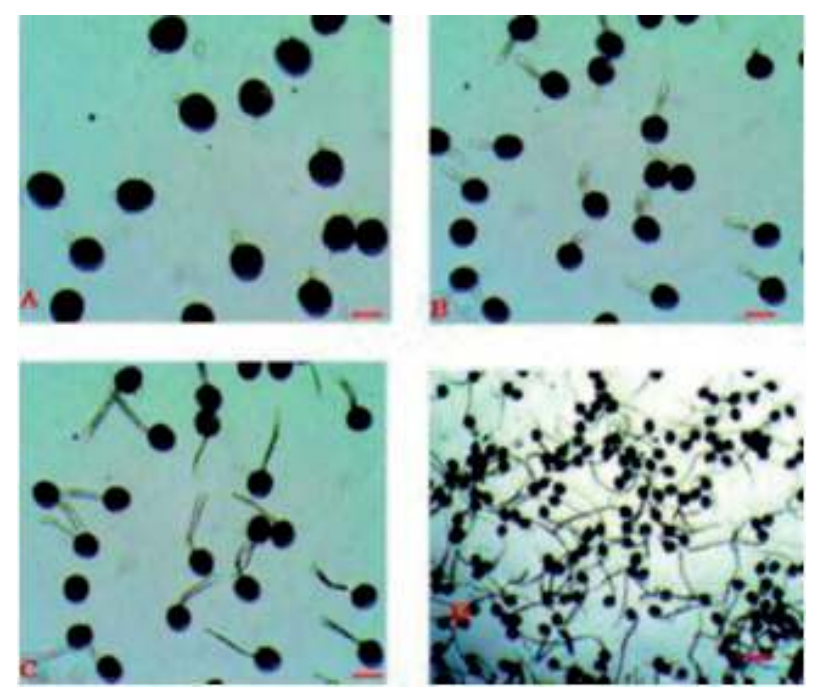

Figure 1. Wheat in vitro pollen germination (a) initiation of pollen germination (b, c, d) pollen germination after 5, 10, and $15 \mathrm{~min}$ of incubation. 


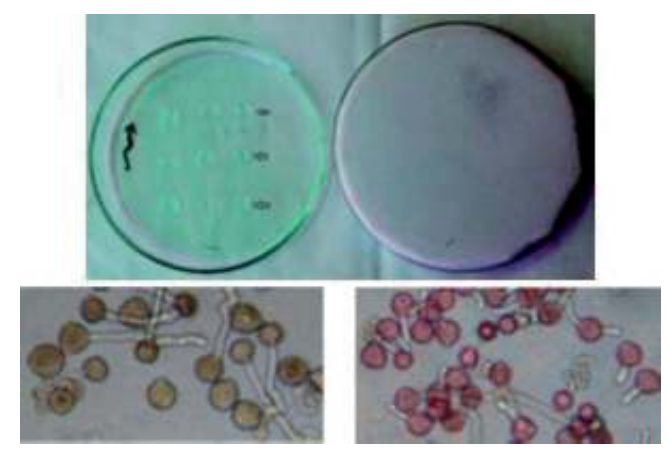

Figure 2. PGM droplet technique. (a) Incubation chamber showing $3 \times 3$ combination of media; (b) unstained pollen tubes; (c) pollen tube with acid fuchsine.

In our experiments initially liquid medium was used but profuse pollen bursting was seen due to quick hydration. To overcome this problem later agarified media were used by adding 0.5 to $1 \%$ agar to pollen germination medium. PGM droplet technique is a further refined technique which may be used effectively to fix the initial levels of inorganic salts level for factorial experiments. Each season, at least 200-300 fresh media were prepared and tested. This allowed large number of media to be tested in a single day, thus avoiding preparation of fresh medium each time and furthermore, more than two genotypes or species could be tested simultaneously.

\section{Effect of different components of pollen germination medium (PGM) on pollen germination}

Sugars: The sugar in the medium acts as an osmotic regulant which regulates the diffusion rate of water from the medium into pollen grains [16] and sucrose is generally used in PGM. The failure of pollen to germinate and its bursting may indicate lack of sugars within pollen grains and critical dependence on external supply. Sucrose has given satisfactory pollen germination for pigeonpea, wild pigeonpeas and wild brinjals whereas it was a poor osmatic regulant for pollen of wheat, rye and brinjal. Maltose was used as carbon source for these species.

Boron and calcium nitrate: The mineral requirements are also different for any two species. Pollen grains are believed to be deficient in boron, which is normally compensated by high levels of boron present in stigma and style. Boron combines with sugar to form a sugar-borate complex which facilitates translocation of sugar molecules. Boron is reported to be toxic to plants even at as low as $5.1 \mathrm{ppm}$ [17]. However, pollen seems to tolerate very high concentration of boron. Visser [18] showed that certain species of crop plants require as much as 1200 ppm boric acid for optimal germination and tube growth. Boron deficiency leads to pollen tube bursting as its required in the pollen wall structure [19]. Calcium is involved in cationic balance and is essential for tube elongation [7]. Pollen germination involves many ions with $\mathrm{Ca}^{2+}$ as the key player and extracellular calcium proved essential for pollen tip growth [20]. It was observed that the grass pollen (wheat and rye) requires very low levels of these minerals (30-50 $\mathrm{mg} \mathrm{l}^{-1}$ ) as compared to the dicots (pigeonpea and brinjal) (300-400 $\mathrm{mg} \mathrm{l}^{-1}$ ). 
Polyethylene glycol (PEG): It is known to be a non-penetrating osmotic agent that decreases water potential of culture medium [21]. In pollen grains, PEG is considered to regulate the permeability of plasma membrane and to give stability to the pollen tube membrane [6] and to give stability to the pollen tube membrane. PEG of different molecular weight has been in pollen cultures of different species and in all cases it has a promontory effect $[4,6,22]$. Generally $10-15 \%$ of PEG was added to PGM. PEG 4000 was preferred for pigeonpea and brinjal whereas wheat and rye pollen germination satisfactorily with addition of PEG 6000 .

Peptone: Inclusion of peptone arrested pollen tip bursting in wheat at concentration 80-120 $\mathrm{mg} \mathrm{l}^{-1}$ which was used in PGM for the first time [2]. Peptone has been used in plant tissue culture for various effects such as induction of shoot regeneration in avocado [23], promotion of hairy root formation in ginseng [24] etc. Addition of peptone, contained pollen tube burst to a great extent, it was less than $20 \%$ as compared to $>85 \%$ in the medium which is devoid of peptone however, the level of peptone varied with genotypes.

$\varepsilon$-Amino caproic acid (EACA): It is an amino acid derivative, a saturated six carbon fatty acid $\left(\mathrm{C}_{6} \mathrm{H}_{12} \mathrm{O}_{2}, \mathrm{CH}_{3}\left(\mathrm{CH}_{2}\right)_{4}-\mathrm{COOH}\right)$ which occurs in milk fats. This immunosuppressor has been used to overcome self-incompatibility and incongruity in Phaseolus [25] and Vigna [26, 27]. It has been used as a component of PGM of pigeonpea for the first time [1] and subsequently in the medium of wheat and rye $[2,10]$.

Tryptone: It was good growth-stimulating nitrogen sources used in the cultivation of Trichoderma hamatum and T. harzianum [28]. It was found to be the best organic nitrogen source for kefiran production by Lactobacillus kefiranofaciens (Dainiel et al., 2015), asparaginase production from Enterobacter cloacae [29], production of biosurfactant by Bacillus subtilis [30]. In rye pollen germination, tryptone at $50-75 \mathrm{mg}$ concentration gave satisfactory and reproducible level of pollen germination [2].

Besides many organic supplements were added to the PGM to enhance smooth pollen tube growth such as casein hydrolysate, vitamins etc.

\section{A protocol to standardize in vitro pollen germination medium}

To standardize pollen germination medium for any crop initially a set of media are used. Based on the response, one of the media is picked up and modified. Here a procedure to develop a PGM for pigeonpea and its wild species is discussed. Initially two sets of key media(PGM) were used Set I consisted of Brewbaker and Kwack (BK) medium [7] with 1\% agar at different levels of sucrose viz., 10, 20, 30 and 40\% (A-D). With the addition of polyethylene glycol (PEG) 4000 at 15\% concentration to each of A, B, C and D; the media E, F, G and $\mathrm{H}$, respectively, were obtained. These were designated as Set II.

Composition of Brewbaker and Kwack's (BK) medium 


\begin{tabular}{ll}
\hline Sucrose & $10 \%$ \\
Boric acid & $100 \mathrm{mg} \mathrm{l}^{-1}$ \\
Calcium nitrate & $300 \mathrm{mg} \mathrm{l}^{-1}$ \\
Potassium nitrate & $100 \mathrm{mg} \mathrm{l}^{-1}$ \\
Magnesium sulfate & $200 \mathrm{mg} \mathrm{l}^{-1}$ \\
\hline
\end{tabular}

Key media

\begin{tabular}{ll}
\hline Set I & Set II \\
\hline A. $10 \%$ sucrose + BK salts + 1\% agar & E. Medium A + 15\% PEG 4000 \\
B. $20 \%$ sucrose + BK salts + 1\% agar & F. Medium B + 15\% PEG 4000 \\
C. $30 \%$ sucrose + BK salts + 1\% agar & G. Medium B + 15\% PEG 4000 \\
D. $40 \%$ sucrose + BK salts + 1\% agar & H. Medium B + 15\% PEG 4000
\end{tabular}

Based on the germination/initiation of germination and bursting of pollen, one of the key media was first selected (Figure 3). The complete medium for each species was then standardized by altering the concentration of sucrose, boric acid and/or calcium nitrate one by one to obtain maximum pollen germination and good pollen tube growth. First sucrose concentration and temperature were varied to prevent bursting of pollen before germination. Secondly, varying concentrations of boric acid was tried viz., 50, 100, ... 300 ppm keeping 300 ppm of calcium nitrate (as in BK medium) and other components unchanged. Lastly, the optimum concentration of calcium nitrate was determined (100, $200, \ldots 600 \mathrm{ppm})$. The observations were recoded for three best concentrations of each boric acid and calcium nitrate.

\subsection{Standardization of in vitro pollen germination medium for C. platycarpus}

In the medium (B) containing 20\% sucrose, 1\% agar and standard Brewbaker and Kwack medium's salts, pollen of C. platycarpus showed $99.15 \%$ germination and tube length over $172 \mu \mathrm{m}$ in $1 \mathrm{~h}$ duration at $20.5^{\circ} \mathrm{C}$. Lowering the concentration of sucrose to $10 \%$ (medium A) and leaving other constituents unchanged gave $61.60 \%$ germination with a mean tube length of over $83.88 \mu \mathrm{m}$. Though the medium (C) containing 30\% sucrose gave $94.25 \%$ germination, the tube length was reduced considerably $(33 \mu \mathrm{m})$, also pollen tube burst at the tips.

The best medium which gave $99.15 \%$ germination for in vitro pollen germination and pollen tube growth of $C$. platycarpus was 
Sucrose

Boric acid

Calcium nitrate

Magnesium sulfate

Potassium nitrate

Agar

Temperature
$20 \%$

$100 \mathrm{mg} \mathrm{l}^{-1}$

$300 \mathrm{mg} \mathrm{l}^{-1}$

$200 \mathrm{mg} \mathrm{l}^{-1}$

$100 \mathrm{mg} \mathrm{l}^{-1}$

$1 \%$

$20.5 \pm 2{ }^{\circ} \mathrm{C}$

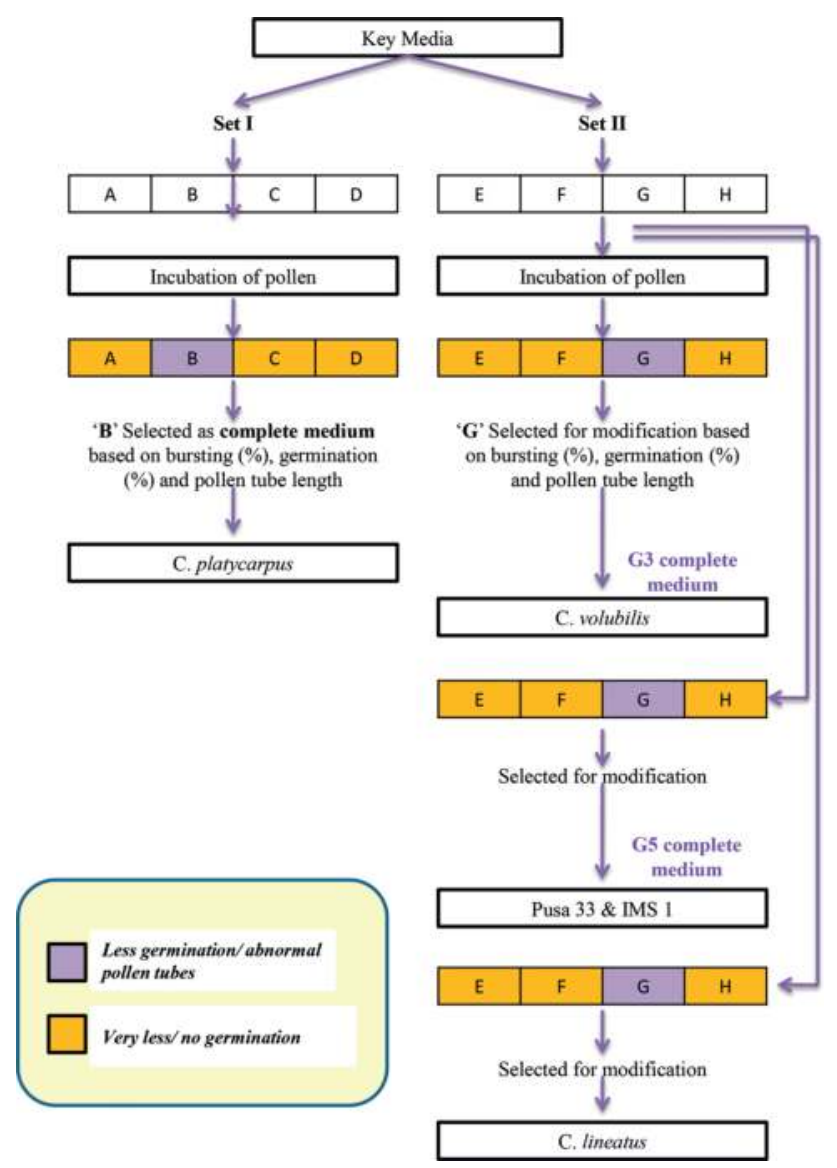

Figure 3. Procedure for standardization of in vitro pollen germination medium of Cajanus spp. 


\subsection{Standardization of in vitro pollen germination medium for C. volubilis}

On key media G (from Set II) the pollen of C. volubilis showed initiation of germination (budding) but almost all pollen grain showed bursting before or after budding. To contain bursting of pollen, sucrose level was increased to $35 \%$ and also the temperature was reduced to $18^{\circ} \mathrm{C}$.

In order to improve germination, first boric acid concentration was altered keeping $\mathrm{Ca}\left(\mathrm{NO}_{3}\right)_{2}$ at $300 \mathrm{ppm}$. At $250 \mathrm{ppm}$, maximum pollen germination was obtained (approximately 63\%) and increasing or decreasing boric acid concentration over $250 \mathrm{ppm}$ did not improve germination.

Then, the concentration of calcium nitrate was modified keeping boric acid concentration at $250 \mathrm{ppm}$ to further improve the germination of $\mathrm{C}$. volubilis pollen. At $100 \mathrm{ppm} \mathrm{Ca}\left(\mathrm{NO}_{3}\right)_{2}$, pollen of C. volubilis showed $94.6 \%$ germination and pollen tube growth of $27.47 \mu \mathrm{m}$. C. volubilis showed $94.26 \%$ germination and pollen tube growth of $27.47 \mu \mathrm{m}$. Increasing the $\mathrm{Ca}\left(\mathrm{NO}_{3}\right)_{2}$ concentration to $200 \mathrm{ppm}$ showed. The complete pollen germination medium for C. volubilis has the following constituents:

\begin{tabular}{ll}
\hline Sucrose & $35 \%$ \\
Calcium nitrate & $100 \mathrm{mg} \mathrm{l}^{-1}$ \\
Potassium nitrate & $100 \mathrm{mg} \mathrm{l}^{-1}$ \\
Magnesium sulfate & $200 \mathrm{mgl}^{-1}$ \\
Polyethylene glycol & $15 \%$ \\
Agar & $1 \%$ \\
Temperature & $18 \pm 1^{\circ} \mathrm{C}$ \\
\hline
\end{tabular}

This gives $94.26 \%$ pollen germination.

\subsection{Standardization of in vitro pollen germination media for C. cajan vars. Pusa 33 and IMS-1}

In the medium D (Set I) only initiation of germination was observed whereas no germination was observed in media A, B and C. On varying the concentrations of boric acid and calcium nitrate, it was observed that the medium with $40 \%$ sucrose, $250 \mathrm{ppm} \mathrm{H}_{3} \mathrm{BO}_{3}, 300 \mathrm{ppm} \mathrm{Ca}$ $\left(\mathrm{NO}_{3}\right)_{2}, 1 \%$ agar and BK salts gave $43.80 \%$ germination with abnormal pollen tubes.

From Set II, medium G showed over 45\% germination (Figure 2) but there was a lot of bursting of pollen grains; medium F also showed little germination. To control the bursting of pollen grains sucrose level was raised to $37.5 \%$ and further, different combinations of boric acid and calcium nitrate were tried. Even though over $87 \%$ germination was seen, almost all the pollen grains showed bursting after germination. Among the permutations 
and combinations of media tried by changing the concentration of boric acid and calcium nitrate, six combinations showed better germination (70-80\%) but accompanied with bursting of pollen tubes.

\subsubsection{Pretreatments}

In order to standardize optimal media for pollen germination different methods of preconditioning the pollen were attempted. Heat treatment of pollen at $40^{\circ} \mathrm{C}$ for $30 \mathrm{~min}$ or at $60^{\circ} \mathrm{C}$ for $20 \mathrm{~min}$ did not improve germination of C. cajan pollen. Pre-hydration for $30 \mathrm{~min}$ in Petri dish lined with moist filter paper also did not improve germination. The stamen of pigeonpea is diadelphous (five short and five long stamens). Pollen extracted separately from short and long stamens showed approximately $70 \%$ germination. Pollen extracted from single anthers also showed about $70 \%$ germination. Thus, germination percentage did not vary between different anthers. Out of six combinations of media tried, the PGM with 250 ppm boric acid and 300 ppm calcium nitrate showed maximum normal pollen tubes.

Another pre-treatment of pollen was tried by incubating young buds ( $12 \mathrm{~h}$ or $36 \mathrm{~h}$ before anthesis) at $20.5^{\circ} \mathrm{C}$ in

(a) Petri dish lined with moist filter paper for $36 \mathrm{~h}$.

(b) Agarified medium containing 37.5\% sucrose in (a) for $36 \mathrm{~h}$.

(c) Agarified medium containing $37.5 \%$ sucrose $+15 \%$ PEG in (a) for $36 \mathrm{~h}$

(d) Pollen germination media for $12 \mathrm{~h}$

(e) Pollen germination media for $36 \mathrm{~h}$.

Then upon anther dehiscence, pollen was collected and germination was tested on six different media. The pollen from treatments (a), (b) and (c) showed good germination on medium $\mathrm{G}_{5}$ but burst soon after.

For treatments (d) and (e) media $G_{1}-G_{6}$ were used both for pre-treatments and germination tests. The pollen from the treatment $(\mathrm{d})$ showed much variation for germination and bursting. Pollen extracted from the treatment (e) showed improved germination for C. cajan var. Pusa 33 and IMS-1. Among the media tested $\left(G_{1}\right.$ to $\left.G_{6}\right)$ the medium $\left(G_{5}\right)$ with 250 ppm $\mathrm{H}_{3} \mathrm{BO}_{3}$ and $300 \mathrm{ppm} \mathrm{Ca}\left(\mathrm{NO}_{3}\right)_{2}$ showed over $92 \%$ germination for both varieties. Besides media $\mathrm{G}_{3^{\prime}} \mathrm{G}_{4}$ and $\mathrm{G}_{6}$ also showed over $90 \%$ germination but there was pollen tube bursting. The result indicated pre-treatment of young buds ( $36 \mathrm{~h}$ before anthesis) in PGM $\left(\mathrm{G}_{5}\right)$ for $36 \mathrm{~h}$ and germinating pollen in the same PGM gave over $92 \%$ germination $\mathrm{Ca}\left(\mathrm{NO}_{3}\right)_{2}$ some other media $\left(\mathrm{G}_{3^{\prime}} \mathrm{G}_{4}\right.$ and $\left.\mathrm{G}_{6}\right)$ also showed over $90 \%$ pollen germination but there was bursting of pollen tubes at tips and variation in pollen tube length.

Thus, the complete media for both Pusa-33 and IMS-1 should have the following composition: 


\begin{tabular}{ll}
\hline Sucrose & $37.5 \%$ \\
Boric acid & $250 \mathrm{mg} \mathrm{l}^{-1}$ \\
Calcium nitrate & $300 \mathrm{mg} \mathrm{l}^{-1}$ \\
Potassium nitrate & $100 \mathrm{mg} \mathrm{l}^{-1}$ \\
Magnesium sulfate & $300 \mathrm{mg} \mathrm{l}^{-1}$ \\
PEG 4000 & $15 \%$ \\
Agar & $1 \%$ \\
Temperature & $20.5 \pm 20^{\circ} \mathrm{C}$ \\
\hline
\end{tabular}

To the above medium EACA at a concentration of $250-750 \mathrm{mg}^{-1}$ was added to arrest pollen tip bursting.

The results of studies on in vitro pollen germination of Cajanus cajan and its wild species are summarized in Table 1.

Based on the initial tests on $C$. lineatus it was found that modification of medium " $G$ " could give optimum germination but due to non-availability of pollen, PGM could not be optimized.

\begin{tabular}{llll}
\hline Optimal media composition & C. platycarpus & C. volubilis & C. cajan vars. Pusa-33 and IMS-1 \\
\hline Sucrose $(\%)$ & 20 & 35 & 27.5 \\
Boric acid (ppm) & 100 & 250 & 250 \\
Calcium nitrate (ppm) & 300 & 100 & 300 \\
Potassium nitrate & 100 & 100 & 100 \\
Magnesium sulfate & 200 & 200 & 200 \\
PEG 4000 (\%) & - & 15 & 15 \\
Agar $(\%)$ & 1 & 1 & 1 \\
Incubation period $(\mathrm{h})$ & 1 & 3 & 3 \\
Incubation temperature $\left({ }^{\circ} \mathrm{C}\right)$ & 20.5 & 18 & 20.5 \\
\% Pollen germination & 99.15 & 94.26 & 92.52 \\
Pollen tube length $(\mu \mathrm{m})$ & $172.56 \pm 0.315$ & $27.47 \pm 0.933$ & $16.34 \pm 0.264$ \\
\hline
\end{tabular}

Table 1. Results of in vitro pollen germination of $\boldsymbol{C}$. cajan and its two wild relatives. 


\subsection{Varietal response to PGMs}

It was noticed that there are genotypic differences for pollen germination. In pigeonpea, among the genotypes tested, IDTSP51 alone did not require EACA, but for others the requirement varied $\left(250-750 \mathrm{mg} \mathrm{l}^{-1}\right)$. Similar response was seen with wheat pollen germination. The medium supporting more than $90 \%$ pollen germination were selected for each genotype though some of them showed pollen tube bursting which indicated the need for fine tuning of the medium. The genotypes HW 971 and HW 741 responded well in M19 giving $>95 \%$ pollen germination and pollen tube length of $>400 \mu \mathrm{m}$. This is adjudged as the best medium since it did not require supplementing either EACA or peptone. It is noted that some genotypes (HD 2833, HW 971, HW 1095 etc.) require EACA alone in PGM whose response were at par with medium having EACA + peptone. Some varieties such as MACS 6195, HW 1095 etc. showed better responses (>92\% germination) in PGM with a combination of EACA (500 or $750 \mathrm{mg}$ ) and peptone water $(100 \mathrm{mg})$. These varieties responded poorly when peptone water was increased beyond $100 \mathrm{mg}$ which reduced the pollen tube length (Table 2).

\begin{tabular}{|c|c|c|c|c|}
\hline Variety & $\begin{array}{l}\text { Pollen germination } \\
\text { medium }\end{array}$ & $\begin{array}{l}\text { Pollen germination } \\
(\%)\end{array}$ & $\begin{array}{l}\text { Pollen tube length }(\mu \mathrm{m}) \\
(\text { mean } \pm \text { S.E) }\end{array}$ & $\begin{array}{l}\text { Range for } \\
\text { pollen tube } \\
\text { length }(\mu \mathrm{m})\end{array}$ \\
\hline \multirow[t]{6}{*}{ HD2833 } & ${ }^{*} \mathrm{M} 19+500 \mathrm{E}$ & 97.9 & $418.8 \pm 15.39$ & \\
\hline & $\mathrm{M} 19+750 \mathrm{E}$ & $94.32 \pm 3.67$ & $667.7142 \pm 32.18$ & \\
\hline & $\mathrm{M} 19+500 \mathrm{E}+100 \mathrm{P}$ & $97.51 \pm 2.98$ & $553.75 \pm 23.14$ & $334.37-713.00$ \\
\hline & $\mathrm{M} 19+750 \mathrm{E}+100 \mathrm{P}$ & $95.38 \pm 3.09$ & $334.37 \pm 18.39$ & \\
\hline & $\mathrm{M} 19+500 \mathrm{E}+120 \mathrm{P}$ & $97.12 \pm 1.87$ & $680.00 \pm 24.255$ & \\
\hline & $\mathrm{M} 19+750 \mathrm{E}+120 \mathrm{P}$ & $97.22 \pm 1.74$ & $713.0 \pm 21.55$ & \\
\hline \multirow[t]{2}{*}{ HW2044 } & $\mathrm{M} 19+500 \mathrm{E}$ & $98.02 \pm 1.03$ & $265.60 \pm 9.88$ & $265.60-467.50$ \\
\hline & $\mathrm{M} 19+750 \mathrm{E}$ & $98.01 \pm 0.076$ & $467.5 \pm 9.55$ & \\
\hline \multirow[t]{2}{*}{ HW5207 } & $\mathrm{M} 19+750 \mathrm{E}$ & $98.0 \pm 0.043$ & $313.529 \pm 12.45$ & $246-350.62$ \\
\hline & $\mathrm{M} 19+500 \mathrm{E}+120 \mathrm{P}$ & $98 \pm 0.054$ & $350.625 \pm 14.91$ & \\
\hline \multirow[t]{3}{*}{ MACS 6145} & M19 & $98.11 \pm 0.87$ & $360.58 \pm 12.05$ & $360.58-603.13$ \\
\hline & $\mathrm{M} 19+750 \mathrm{E}+100 \mathrm{P}$ & $97.21 \pm 1.54$ & $603.13 \pm 22.48$ & \\
\hline & $\mathrm{M} 19+750 \mathrm{E}+120 \mathrm{P}$ & $972.63 \pm 2.11$ & $546.25 \pm 26.89$ & \\
\hline \multirow[t]{2}{*}{ HW 971} & $\mathrm{M} 19+500 \mathrm{E}$ & $98.13 \pm 1.42$ & $462.50 \pm 18.76$ & $462.50-551.25$ \\
\hline & $\mathrm{M} 19+500 \mathrm{E}+100 \mathrm{P}$ & $98.0 \pm 0.6$ & $551.25 \pm 25.85$ & \\
\hline \multirow[t]{2}{*}{ HW 741} & M19 & $98.23 \pm 0.042$ & $403.75 \pm 21.13$ & $241.87-403.75$ \\
\hline & $\mathrm{M} 19+500 \mathrm{E}$ & $97.23 \pm 1.99$ & $241.87 \pm 8.55$ & \\
\hline HW1085 & $\mathrm{M} 19+500 \mathrm{E}$ & $98.18 \pm 1.11$ & $244.375 \pm 11.44$ & \\
\hline HW1095 & $\mathrm{M} 19+500 \mathrm{E}$ & $98.01 \pm 0.43$ & $268.75 \pm 11.83$ & $190-371.87$ \\
\hline
\end{tabular}




\begin{tabular}{lllll}
\hline Variety & $\begin{array}{l}\text { Pollen germination } \\
\text { medium }\end{array}$ & $\begin{array}{l}\text { Pollen germination } \\
\mathbf{( \% )}\end{array}$ & $\begin{array}{l}\text { Pollen tube length }(\mu \mathrm{m}) \\
(\mathrm{mean} \pm \mathrm{S} . \mathrm{E})\end{array}$ & $\begin{array}{l}\text { Range for } \\
\text { pollen tube } \\
\text { length }(\mu \mathrm{m})\end{array}$ \\
\hline $\mathrm{M} 19+750 \mathrm{E}+100 \mathrm{P}$ & $92.91 \pm 4.53$ & $371.87 \pm 16.36$ \\
$\mathrm{M} 19+500 \mathrm{E}+120 \mathrm{P}$ & $90.82 \pm 4.76$ & $278.125 \pm 18.13$ \\
$\mathrm{M} 19+750 \mathrm{E}+120 \mathrm{P}$ & $96.37 \pm 3.75$ & $190 \pm 3.65$ \\
\hline
\end{tabular}

$\mathrm{P}=$ peptone; $\mathrm{E}=\mathrm{EACA} .{ }^{*} \mathrm{M} 19=19 \%$ Maltose $+13 \%$ PEG $6000+50 \mathrm{mg} \mathrm{l}^{-1}$ boric acid $+30 \mathrm{mg} \mathrm{l}^{-1}$ calcium nitrate $+\mathrm{BK}$ salts $+1 \%$ agar.

Table 2. Response of wheat genotypes in pollen germination medium.

Among the varieties tested, two of them viz., HD 2833 and HW 1095 showed more that $94 \%$ in all the media tested. The genotype HD 2833 showed the maximum pollen tube length of $713 \mu \mathrm{m}$ in PGM with $750 \mathrm{mg} \mathrm{l}^{-1}$ EACA and $120 \mathrm{mg} \mathrm{l}^{-1}$ peptone and the pollen of HW1095 achieved a mean pollen tube length of $190 \mu \mathrm{m}$ in the same medium The variety HD 2833 showed a mean pollen tube length in the range of 334.37 to $713 \mu \mathrm{m}$ followed by MACS6145 with 360.58 to $603.13 \mu \mathrm{m}$ and HW671 with 462.50 to $551.25 \mu \mathrm{m}$ for mean pollen length. Similar kind of genotypic differences for pollen germination requirement have also been reported [1].

\section{Conclusion}

A simple or a complex medium may be developed to suit the germination requirement of pollen (binucleate or trinucleate pollen). The protocol suggested would give a better guidance in development of PGM. The author has developed pollen germination medium (PGM) for many crops viz. pigeonpea and its wild species, wheat, rye and brinjal by using the base constituents of PGM of Brewbaker and Kwack [7]. These media were supplemented with polyethylene glycol, e-amino caproic acid, peptone etc. besides the addition of BK salts. Grasses pollen so far considered as recalcitrant can also be germinated in the artificial medium e.g. wheat and rye. The grass pollen is released at high moisture content (30-40\%) as compared to $1-5 \%$ in the case of orthodox species. This trait makes it unsuitable for in vitro germination. With combination of maltose, PEG and tryptone/peptone contained the initial pollen bursting and resulted in successful pollen germination of wheat and rye. The grasses pollen was so far classified as recalcitrant [31]. It is observed that monocots require low salt content than the dicots in the pollen germination medium. Also wild species require minimal medium than the domesticate ones.

\section{Author details}

Jayaprakash P

Address all correspondence to: jpsarit@iari.res.in

ICAR-Indian Agricultural Research Institute, The Nilgiris, Tamil Nadu, India 


\section{References}

[1] Jayaprakash P, Sarla N. Development of an improved medium for germination of Cajanus cajan (L.) Millsp. pollen in vitro. Journal of Experimental Botany. 2001;52:851-855

[2] Jayaprakash P, Annapoorani S, Vikas VK, Sivasamy M, Kumar1 J, Saravannan K, Punniakotti, Sheeba D. An improved in vitro germination medium for recalcitrant bread wheat pollen (Triticum aestivum L.). Indian Journal of Genetics and Plant Breeding. 2015;75(4):446-452

[3] Linskens HF. Pollen. Handbuch der Pflanzenphysiologie. Vol. XVIII1967. pp. 368-406

[4] Zhang HQ, Croes AF. A new medium for pollen germination in vitro. Acta Botanica Neerlandica. 1982;31:113-119

[5] Shivanna KR, Saxena NP, Seetharama N. An improvised medium for in vitro pollen germination and pollen tube growth of chickpea. International Chickpea and Pigeonpea Newsletter. 1997;4:28-29

[6] Read SM, Clarke A, Bacic A. Stimulation of growth of cultured Nicotiana tabacum W-38 pollen tubes by polyethylene glycol and Cu(II) salts. Protoplasma. 1993;177:1-14

[7] Brewbaker JL, Kwack BH. The calcium ion and substances influencing pollen growth. In: Linskens HF, editor. Pollen Physiology and Fertilization. Amsterdam: Elsevier North Holland; 1964. pp. 145-151

[8] Roberts IN, Gaunde TC, Harrod G, Dickinson HG. Pollen stigma interaction in Bracssica oleracea: A new pollen germination medium and its use in elucidating the mechanism of self-incompatibility. Theoretical and Applied Genetics. 1983;65:231-238

[9] Cheng C, McComb JA. In vitro germination of wheat pollen on raffinose medium. New Phytologist. 1992;120:459-462

[10] Jayaprakash P, Sheeba D, Vikas VK, Sivasamy M, Kumar J, Annapoorani S, Krishan N. A reproducible in vitro pollen germination medium for recalcitrant cereal rye pollen (Secale cereale L.): Effect of tryptone. Indian Journal of Genetics and Plant Breeding. 2017;77(1):25-31

[11] Rodriguez-Enriquez MJ, Mehdi S, Dickinson HG, Grant-Downton RT. A novel method for efficient in vitro germination and tube growth of Arabidopsis thaliana pollen. New Phytologist. 2011;197:668-679

[12] Shivanna KR, Rangaswamy NS. Test for pollen viability. In: Pollen Biology: A Laboratory Manual. New Delhi: Narosa; 1992. p. 33

[13] Shivanna KR and Rangaswamy NS. Pollen Biology: Laboratory Manual. 1992

[14] Singh IS, Bharti IS, Nandwal AS, Goswami C, Verma SK. Effect of temperature on in vitro pollen germination in pigeonpea. Biologia Plantarum. 1992;34 
[15] Jayaprakash P, Sabesan T. In vitro pollen germination of some wild species of pigeonpea (Cajanus cajan) using PGM droplet technique. Indian Journal of Genetics and Plant Breeding. 2013;73:211-215

[16] Johri BM, Vasil IK. Physiology of pollen. The Botanical Review. 1961;27:325-381

[17] Vasil K. Effect of boron on pollen germination and pollen growth. In: Linskens JF, editor. Pollen Physiology and Fertilization. Amsterdam, The Netherlands: North Holland Publishing Co.; 1963

[18] Visser T. Germination and storage of pollen. Meded Landbouwhogeschool Wageningen. $1955 ; 55: 1-68$

[19] Acar I, Ak BE, Sarpkaya K. Effect of boron and gibberellic acid on in vitro pollen germination of pistachio (Pistacia vera L.). African Journal of Biotechnology. 2010;32:5126-5130

[20] Steinhorst L, Kudla J. Calcium-A central regulator of pollen germination and tube growth. Biochimica et Biophysica Acta. 2013;1833:1573-1581

[21] Powell GM III. Polyethylene glycol. In: Davidson RE, editor. Handbook of Water Soluble Gums and Resins. New York: McGraw-Hill; 1980. pp. 1801-1831

[22] Ferrari TE, Wallace DH. Germination of Brassica pollen and expression of incompatibility in vitro. Euphytica. 1975;24:751-765

[23] Nhut DT, Thi NN, Khiet BLT, Luan VQ. Peptone stimulates in vitro shoot and root regeneration of avocado (Persia Americana Mil). Science Horticulture. 2008;115:124-128

[24] Sivakumar G, Yu KW, Hahn EJ, Pack YY. Optimization of organic nutrients for ginseng hairy roots production in large scale bioreactors. Current Science. 2005;89:641-649

[25] Nagarajan P, Walton PD. The effect of $\varepsilon$-amino caproic acid on self-incompatibility and incongruity in Phaseolus. Journal of Horticultural Science. 1988;63:433-450

[26] Baker LR, Chen NC, Park HG. Effect of an immunosuppressant on an interspecific cross of genus Vigna. Horticultural Science. 1975;10:313

[27] Chen NC, Parrot HF, Jacob T, Baker LR, Carlson PS. Interspecific hybridization of food legumes by unconventional methods of breeding. In:Proceedings of the First International Mungbean Symposium.Aug 16-19, Univ. Philipines, Los Bonas. 1978. pp. 247-252

[28] Bianca Caroline RR, Brochetto-Braga MR, Tauk-Tornisielo SM, Carmona EC, Arruda VM, Netto JC. Comparative growth of Trichoderma strains in different nutritional sources, using bioscreening C automated system. Brazilian Journal of Microbiology. 2009;40: $404-410$

[29] Anjana S, Islam H. Optimization of medium components for extracellular glutaminase free asparaginase from enterobacter cloacae. International Journla of Current Microbiological Applied Science. 2015;4(1):296-309 
[30] Gudina JE, Elisabete CF, Rodrigues AI, José AT, Lígia RR. Biosurfactant production by Bacillus subtilis using corn steep liquor as culture medium. Frontiers Microbiology. 2015:6-59

[31] Franchi GG, Piotto B, Nepi M, Baskin CC, Baskin J, Pacini E. Pollen and seed desiccation tolerance in relation to degree of developmental arrest, dispersal, and survival. Journal of Experimental Botany. 2011:1-15 